\title{
Pengetahuan Gizi Ibu dan Praktik Diversifikasi Makanan Keluarga di Kelurahan Purworejo, Kecamatan Margoyoso, Pati
}

\author{
Loviana Mufida $^{1}$, Agus Sartono ${ }^{2}$, Mufnaetty ${ }^{3 *}$ \\ ${ }^{123}$ S1 Gizi FIKKES Universitas Muhammadiyah Semarang \\ nettyshofa@yahoo.co.id*
}

\section{ABSTRACT}

In daily observations the pattern of food consumption in the Purworejo village community is not so diverse, there are still mothers who are not posyandu participants so that knowledge related to food diversification is lacking while family income levels are quite varied.The purpose of this study was to determine the relationship between maternal nutritional knowledge, level of family food diversity in Purworejo Village, Margoyoso Pati District.

His study is a quantitative analytic study with a cross sectional approach. The sample of this study was housewives in Purworejo Village, Margoyoso Pati District. The number of samples is 88 households which are determined by systematic random sampling. The variables in this study were measured by interviews and questionnaires. The statistical test used in the variables of nutritional knowledge and family income level is Rank Spearman correlation, while the maternal match variable in the posyandu uses Mann Whitney.

Found $45.5 \%$ of respondents had good nutrition knowledge and $48.9 \%$ had poor nutrition knowledge. There were $69.3 \%$ of respondents did not become Posyandu participants, $52.3 \%$ of respondents had poor food diversification. There is a relationship between maternal nutrition knowledge with food diversification practices and there is no difference in Family Food Diversification Practices based on maternal participation in Posyandu.

Keywords: nutritional knowledge, Food diversification.

\section{PENDAHULUAN}

Indonesia adalah salah satu negara yang sedang berkembang sehingga selalu berupaya untuk melakukan pembangunan di segala bidang termasuk pembangunan di bidang kesehatan. Kekuatan fisik dan mental serta kesehatan yang prima merupakan salah satu yang dapat menentukan keberhasilan pembangunan di Indonesia. Pembangunan kesehatan sebagai bagian dari upaya membangun manusia seutuhnya antara lain diselenggarakan melalui upaya pemenuhan gizi bagi masyarakat. Gizi merupakan salah satu penentu bagi pencapaian peningkatan kualitas SDM di mempengaruhi kelangsungan hidup manusia (Elvina, dkk 2012). Pemenuhan gizi keluarga secara tidak langsung dapat mempengaruhi oleh faktor sosial ekonomi keluarga antara lain: pendapatan keluarga, 
tingkat pendidikan Ibu tentang gizi dan pekerjaan Ibu (Wynsdy dkk, 2017). Gizi berkaitan dengan potensi ekonomi karena dengan gizi akan menentukan perkembangan otak, kemampuan belajar, dan produktifitas kerja (Almatsier, 2010).

Pengetahuan adalah hasil tahu yang merupakan konsep didalam pikiran seseorang hasil seseorang melakukan penginderaan terhadap sesuatu objek tertentu. Orang tua berperan penting dalam memenuhi kebutuhan nutrisi anak (Murashima et al., 2012). Ismi (2014) dalam penelitian menyatakan bahwa ada hubungan antara pengetahuan ibu dengan status gizi balita pada aspek pemahaman pemberian makanan dan implementasi pengetahuan yang diperoleh dalam kehidupan sehari-hari. Pengetahuan ibu tentang gizi secara tidak langsung akan menentukan pemenuhan gizi keluarga, karena ibu sebagai penanggung jawab pemberian makan dalam keluarga. Seorang Ibu dengan pengetahuan gizi yang baik dapat penyediaan makanan yang baik pula untuk keluaga. Pemenuhan zat gizi dipengruhi oleh asupan makanan baik secara kualitas maupun kuantitas serta keragaman pangan yang dikonsumsi.

Penganekaragaman konsumsi pangan disamping untuk meningkatkan ketahanan pangan keluarga dapat juga meningkatkan gizi keluarga karena mampu memenuhi kebutuhan gizi yang seimbang sesui kebutuhan tubuh. Perhatian pada pemenuhan kebutuhan gizi untuk hidup sehat dan bertumbuh kembang harus dilakukan pada saat menyusun hidangan. Kecukupan zat gizi berpengaruh pada kesehatan terutama untuk anak dan kecerdasanya. Kemampuan mengelola makanan sehat yang akan dihidangkan untuk keluarga perlu didasarkan pada pengetahuan yang baik tentang gizi (Santoso dkk, 2009).

Berbagai kajian di bidang gizi dan kesehatan menunjukkan bahwa untuk dapat hidup sehat dan produktif, manusia membutuhkan kurang lebih 45 jenis zat gizi yang harus diperoleh dari makanan yang dikonsumsi, dan tidak ada satu jenis pangan, yang mampu memenuhi seluruh kebutuhan gizi bagi manusia. Untuk memenuhi kebutuhan gizi tersebut, setiap orang perlu mengkonsumsi pangan yang beragam dan bergizi seimbang, serta aman. Dengan mengkonsumsi makanan yang beranekaragam setiap hari, kekurangan zat gizi pada satu jenis makanan, akan dilengkapi oleh keunggulan susunan zat gizi jenis makanan lain, sehingga dapat diperoleh masukan zat gizi yang seimbang. Sebaliknya mengkonsumsi hanya satu 
jenis makanan dalam jangka waktu relatif lama, dapat menderita berbagai penyakit kekurangan zat gizi atau gangguan kesehatan

Kemampuan ibu dalam menyajikan hidangan makanan akan sangat dipengaruhi oleh pengetahuan gizi, status ekonomi dan pendapatan keluarga. Seorang ibu dalam penganekaragaman pangan perlu memiliki pengetahuan mengenai bahan makanan dan zat gizi, serta pengetahuan tentang cara menghidangkan dan cara pengelolaannya. Kondisi ini biasanya berbeda dengan masyarakat di pedesaan yang kurang memperhatikan nilai gizi pada hidangan yang disajikan. Masyarakat pedesaan biasaya lebih mengutamakan pemenuhan rasa lapar, sementara pemenuhan asupan gizi dari hidangan yang disajikan kurang mendapat perhatian.

Kurangnya pengetahuan gizi dan kesehatan orang tua, khususnya ibu merupakan bagian penyebab terjadinya kekurangan gizi. Cara menghidangkan makanan di pedesaan banyak dipengaruhi oleh keadaan sosial ekonomi dan kebudayaan. Masyarakat seringkali dihadapkan pada pantangan makan, misalnya anak kecil tidak diberikan ikan karena dipercaya dapat menyebabkan cacingan, kacang-kacangan tidak diberikan karena dapat menyebabkan sakit perut atau kembung (Supariasa, 2007). Upaya mengubah perilaku berpantang makanan hususnya bagi ibu sebagai orang yang paling dekat dengan anak serta bertanggungjawab pada pemenuhan asupan gizinya, dibutuhkan pengetahuan tentang gizi. Pengetahuan minimal yang harus diketahui seorang ibu adalah tentang kebutuhan gizi, cara pemberian makan, jadwal pemberian makan pada balita, sehingga akan menjamin anak dapat tumbuh kembang secara optimal. Pengetahuan ibu dalam mengelola gizi keluarga salah satunya dapat diperoleh dari keaktifan ibu dalam kegiatan posyandu. Penyuluhan gizi yang dilakukan oleh kader posyandu akan memberikan pemahaman kepada ibu, cara memberikan sajian makanan yang bergizi untuk keluarga.

Br_ Berdasarkan fenomena di atas maka permasalahan dalam penelitian ini yaitu bagaimana Hubungan Pengetahuan Gizi Ibu dengan Praktik Penganekaragaman Pangan keluarga di Desa Purworejo Pati.

\section{METODE PENELITIAN}

Jenis penelitian ini adalah kuantitatif dengan pendekatan belah lintang (Cross Sectional) dan metode survai (Notoatmodjo, 2010). Penelitian 
dilaksanakan di Desa Purworejo Kecamatan Margoyoso Kabupaten Pati pada bulan Oktober 2017 - Maret 2018. Unit analisis penelitian adalah rumah tangga. Populasi dalam penelitian adalah seluruh rumah tangga di Desa Purworejo Kecamatan Margoyoso Pati berjumlah 721 Rumah Tangga. Teknik sampling dalam penelitian menggunakan sistematik random sampling yang dihitung menggunakan rumus minimal sample size dan mendapatkan hasil sampel $87,82 \mathrm{KK}$ atau dibulatkan menjadi 88 KK. Data pengetahuan gizi ibu, dan praktik penganekaragaman pangan keluarga diukur menggunakan melalui kuesioner dan wawancara.

Hasil uji kenormalan data menggunakan Kolmogorov Smirnov menunjukan hasil data tidak berdistribusi normal sehingga untuk analisa selanjutnya menggunaan uji korelasi Rank Spearman sedangkan perbedaan praktik penganekaragaman pangan menggunakan Man Whitney.

\section{HASIL DAN PEMBAHASAN}

\section{A. Karakteristik Responden}

1. Umur Responden

Berdasarkan Gambar 1 ditunjukkan bahwa sebagian besar responden berumur antara 43-55 tahun sebanyak 51 orang $(58,0 \%)$ dan yang paling sedikit kelompok umur 31-42 tahun sebanyak 12 orang $(13,6 \%)$.

\section{Umur Responden}

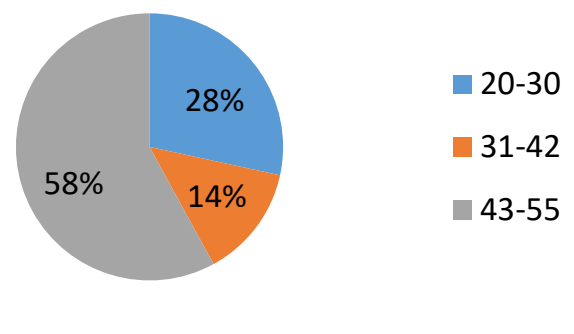

Gambar 1. Karakteristik Responden Berdasarkan Umur

2. Pekerjaan Responden

Gambar 2 menunjukkan bahwa sebagian besar $(71,6 \%)$. responden tidak bekerja atau hanya sebagai ibu rumah tangga .

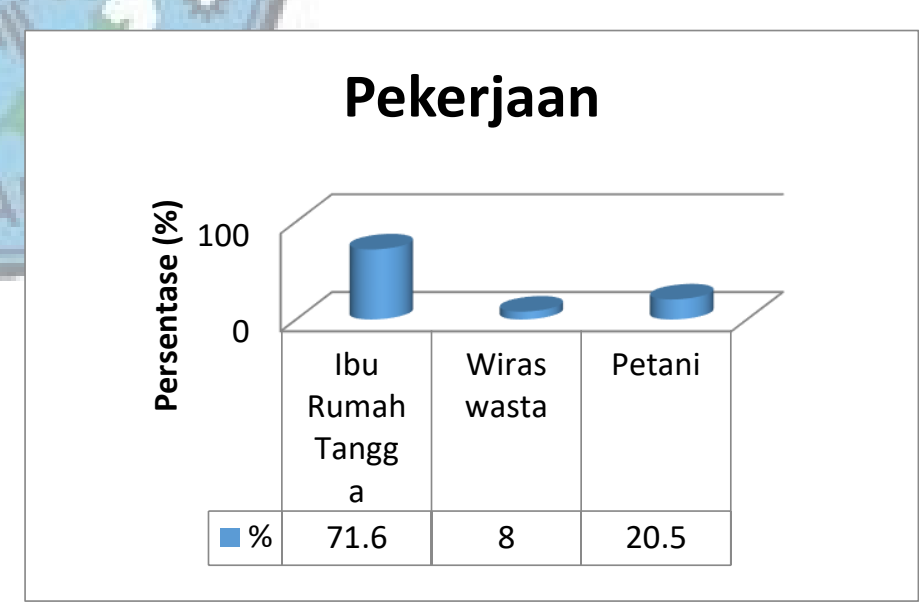

Gambar 2. Karakteristik Responden Berdasarkan Pekerjaan Responden

Gambar 3. menunjukkan bahwa secara umum pendidikan responden dapat 
dikatakan rendah karena sebagian besar responden hanya berpendidikan SD yaitu sebanyak 53 orang $(60,2 \%)$.

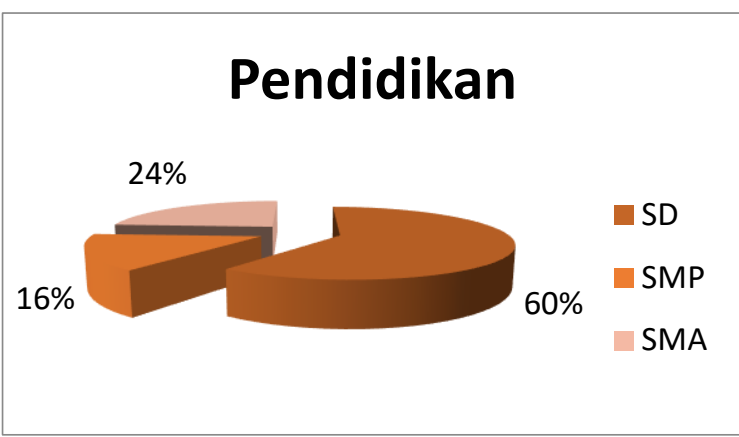

Gambar 3. Karakteristik Responden Berdasarkan Pendidikan

Penemuan penelitian Amalia (2009) menunjukan bahwa tingkat pendidikan seseorang memegang peran dalam merubah sikap menuju hidup bersih dan sehat. Orang tua dengan pendidikan yang tinggi akan mudah menerima perubahan menjadi lebih baik termasuk dalam upaya perbaikan dalam memilih makanan yang bergizi seimbang bagi anaknya. Sebaliknya mayoritas pendidikan responden dalam penelitian ini berpendidikan rendah, rendahnya pendidikan responden dapat menghambat keberhasilan melakukan perubahan perilaku kearah yang lebih baik hususnya dalam memenuhi gizi seimbang yang sesuai kebutuhn anak.

\section{B. Pengetahuan Gizi Ibu}

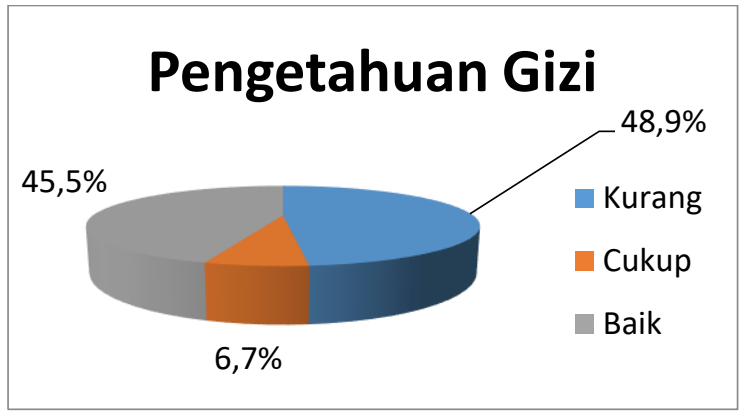

Gambar 4. Pengetahuan Gizi Responden

Hasil penelitian yang ditujukkan pada Gambar 4. bahwa pengetahuan gizi responden dengan kreteria antara yang kurang dan yang cukup hampir sama yaitu untuk kategori kurang sebanyak 48,9\% dan untuk kategori cukup baik sebanyak 45,5\%. Hasil penelitian juga mengungkapkan bahwa Rata-rata skor pengetahuan responden adalah $\pm 9,113$ dengan skor terendah adalah 2 dan tertinggi adalah 14 dengan standar deviasi sebesar 4,052. Penelitian ini menjadi salah satu bukti bahwa tingkat pendidikan yang rendah akan menentukan kurangnya pengetahuan tentang gizi sebagai bagian akibat dari sulitnya melakukan perubahan perilaku.

Tabel 1. Distribusi frekuensi penganekaragaman pangan keluarga

Penganekaragaman Frekuensi Persentase makanan

\begin{tabular}{lcc}
\hline Kurang baik & 46 & 52,3 \\
Baik & 42 & 47,7 \\
\hline Jumlah & 88 & 100 \\
\hline
\end{tabular}


Tabel 1. diketahui bahwa penganekaragaman pangan keluarga dalam kategori kurang baik sebanyak 46 orang $(52,3 \%)$ dan yang kategori baik sebanyak 42 orang $(47,7 \%)$. Rata-rata skor penganekaragaman pangan keluarga sebesar 18,73 $\pm 3,62$. Penelitian juga mengungkapkan Skor penganekaragaman terendah sebesar 13 dan tertinggi 24. Penganekaragaman pangan keluarga ini dihitung berdasarkan banyaknya jenis bahan makanan yang di konsumsi atau di hidangkan meliputi makanan pokok, lauk hewani, lauk nabati sayur dan buah. Makanan yang disajikan ini menjadi kebiasaan keluarga sebagai menu atau hidangan yang biasa disajikan atau tersedia di dalam keluarga responden.

F. Hubungan pengetahuan gizi dengan praktik penganekaragaman pangan

\section{keluarga}

Uji statistik menggunakan korelasi Rank Spearman didapatkan nilai koefisien korelasi sebesar 0,809 dengan nilai $\mathrm{p}$ sebesar $0,000(\mathrm{p}<$ $0,05)$, artinya ada hubungan antara pengetahuan dengan penganekaragaman pangan keluarga dengan kekuatan hubungan yang kuat. Hubungan tersebut dapat dilihat pada gambar berikut :

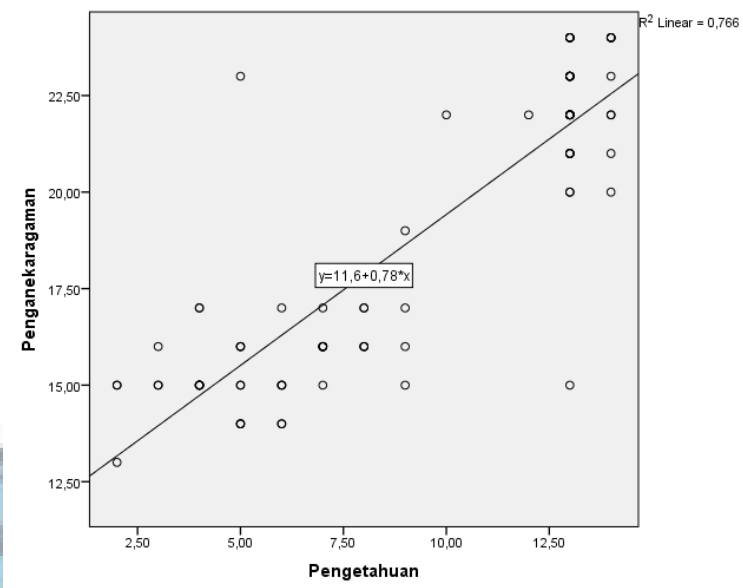

Gambar 5. Hubungan pengetahuan gizi Ibu dengan praktik penganekaragaman pangan keluarga

Berdasarkan Gambar 5. dapat diketahui bahwa kemiringan garis linier bergerak dari bawah ke atas yang menunjukkan adanya hubungan yang positif antara kedua variabel. Artinya apabila pengetahuan meningkat maka penganekaragaman pangan keluarga juga semakin baik. Nilai $\mathrm{r}^{2}$ sebesar 0,766 memiliki arti bahwa pengetahuan memberikan pengaruh terhadap peningkatan penganekaragaman pangan keluarga sebesar $76,6 \%$ pada model penelitian ini sementara sisanya $23,4 \%$ disebabkan oleh faktor lain. 
Hasil penelitian ini sejalan dengan penelitian Adianti (2016) yang menunjukan ada hubungan bermakna antara pengetahuan dengan penganekaragaman makanan. Artinya bahwa dengan pengetahuan yang rendah maka penganekaragaman makanan yang disajikan juga kurang baik, atau kurang memenuhi standar gizi yang mencukupi.

\section{KESIMPULAN DAN SARAN}

\section{A. Kesimpulan}

1. Proporsi responden yang memiliki pengetahuan gizi baik yaitu $40 \mathrm{ibu}(45,5 \%)$ hampir sama dengan proporsi responden yang memiliki pengetahuan gizi kurang yaitu $48,9 \%$.

2. Responden dengan penganekaragaman pangan yang kurang baik berjumlah $=46$ responden $(52,3 \%)$

3. Ada hubungan antara pengetahuan gizi ibu dengan praktik penganekaragaman pangan

\section{B. Saran}

Bagi Puskesmas disarankan untuk dapat meningkatkan kegiatan promosi kesehatan khususnya berkaitan dengan pentingnya gizi seimbang dan penganekaragaman makanan untuk meningkatkan status gizi keluarga dan masyarakat.

\section{DAFTAR PUSTAKA}

Aditianti1, Sri Prihatini dan Hermina, 2016. Pengetahuan, Sikap dan Perilaku Individu Tentang Makanan Beraneka Ragam sebagai Salah Satu Indikator Keluarga Sadar Gizi (KADARZI). Buletin Penelitian Kesehatan, Vol. 44, No. 2, Juni 2016 : 117 - 126

Airin Nurul Hasanah, Alam Bakti Keloko, Lita Sri Andayani. 2012. Gambaran perilaku ibu dalam penyediaan sayur keluarga di kelurahan pasir bidang Kecamatan Sarudik Kabupaten Tapanuli Tengah tahun 2012.

Almatsier, Sunita. 2007. Prinsip Dasar Ilmu Gizi. Jakarta: PT. Gramedia Pustaka Utama.

Ana Retnoningsih dan Suharso. 2005. Kamus Besar Bahasa Indonesia, Semarang: CV. Widya Karya.

Baliwati, Y.F. 2010. Pengantar Pangan dan Gizi. Jakarta: PT. Penebar Swadaya.

Bardosobo, Saptawati., 2009. Penilaian Status Gizi Balita, Diakses dari http://staff.ui.ac.id/system/files/u sers/saptawati.bardosono/materi al/penilaianstatu sgizibalitaantropometri.pdf.

Depkes RI. 2010. Aksi Pangan dan Gizi Nasional. Direktorat Jenderal Bina Kesehatan Masyarakat. Jakarta.

Erly Handayani. 2014. Pengaruh pengetahuan gizi ibu dan 
pendapatan orang tua terhadap pola makan anak balita umur 6 bulan-5tahun di dusun 1 Desa Palumbungan Kecamatan Bobotsari Kabupaten Purbalingga.

Elvina. Helendra. Dan Erismar. (2012). Hubungan Tingkat Pengetahuan Ibu Tentang Gizi Dengan Status Gizi Balita di Desa Sioban Kabupaten Kepulauan

FAO-MOA. 1989. Pendidikan Kependudukan dan Gizi. Suhardjo, penerjemah; Belanda: FAO. Terjemahan dari: Population Education and Nutrition.

Green, L.W \& Kreuter, M.W. 2005. Health promotion plainning an educational and environmental approach. Second edition. Toronto London: Mayfield publishing company.

Gunawan, Ari H. 2009. Sosiologi Pendidikan suatu Analisis Sosiologi tentang Pelbagai Problem Pendidikan. Jakarta: PT Rineka Cipta.

Hassan Shadily. 2008. Kamus Inggris Indonesia, 1990, Gramedia Pustaka Utama.

Ismi, N. 2014. Faktor-Faktor yang Berhubungan dengan Status Gizi Balita Usia 1-5 Tahun di Desa Pekuncen Banyumas. Jurnal Ilmiah Kesehatan. Volume 6, No 1

Kemenkes RI. 2011. Pedoman Umum Pengelolaan Posyandu. Jakarta.

Kementerian Kesehatan RI. 2014. Pedoman Gizi Seimbang. Direktur Jenderal Bina Gizi dan KIA. Jakarta.
Murashima, M., Hoerr, S. L., Hughes, S. O., Kattelmann, K. K., \& Phillips, B. W. (2012). Maternal parenting behaviors during childhood relate to weight status and fruit and vegetable intake of college students. Journal of Nutrition Education and Behavior, 44(6), 556-63

Notoatmodjo, S. 2007. Promosi kesehatan dan ilmu perilaku. Jakarta : Rineka Cipta.

Notoatmodjo, S. 2010. Metodologi penelitian kesehatan. Jakarta : Rineka Cipta.

Notoatmodjo, S. 2010. Promosi kesehatan : Teori dan aplikasi. Cetakan ke2. Jakarta: Rineka Cipta.

Raffalovich, L.E., Monnat, S.M., \& Tsao, H. (2009). Family Income at the Bottom and at the Top: Income Sources and Family Characteristics. Res Soc Stratif Mobil. 2009 December 1; 27(4): 301-309

Riayadi. 2003. Kebiasaan makan masyarakat dalam kaitannya dengan penganekaragaman konsumsi pangan. Prosiding Simposium Pangan dan Gizi serta Kongres IV Bergizi dan Pangan Indonesia. Jakarta.

Santoso, H. dan Yuliati LN, 2009. Manajemen Gizi Institusi. Jakarta : Departemen Pendidikan dan Kebudayaan Direktorat Jenderal Pendidikan Dasar dan Menengah. Direktorat Pendidikan Menengah Kejuruan. Proyek Peningkatan Pendidikan dan Kejuruan Non Teknik II.

Sitorus, MT Felix. 2007. Penelitian Kualitatif: Suatu Perkenalan. 
Bogor: Kelompok Dokumentasi Ilmu-ilmu Sosial.

Soekanto, Soerjono. 2007. Sosiologi suatu Pengantar. Jakarta: P.T.Raja Grafindo.

Sugiyono. 2007. Statistika untuk penelitian. Bandung : Alfabeta.

Sumardi, Mulyanto. 2009. Kemiskinan dan Kebutuhan Pokok. Jakarta: CV. Rajawali.

Supariasa, I Dewa Nyoman. 2007. Penilaian Status Gizi. Jakarta. Penerbit Buku Kedokteran EGC.

Walgito, Bimo. 2009. Pengantar Psikolog Umum. Yogyakarta: C.V Andi Offset

Wynsdy Fajar Apriliana, Luluk Ria Rakhma (2017). Faktor-Faktor Yang Berhubungan Dengan Status Gizi Balita Yang Mengikuti Tfc di Kabupaten Sukoharjo. Jurnal PROFESI (Profesional Islam) Volume 15; No 1.

Yunita Diana Putri Dewi. 2015. Studi pola konsumsi makanan pokok pada penduduk Desa Pagendingan Kecamatan Galis Kabupaten Pamekasan Madura.

Amanda Amalia (2009). Hubungan Antara Pendidikan, Pendapatan Dan Perilaku Hidup Bersih Dan Sehat (Phbs) Pada Pedagang Hidangan Istimewa Kampung (Hik) Di Pasar Kliwon Dan Jebres Kota Surakarta. http://eprints.ums.ac.id/5963/1/J4 $\underline{10050016 . P D F}$ 